Article

\title{
Social License to Operate and Adaptive Co-Marketing: Exchange, Social Capital and Community-Based Social Marketing
}

\author{
C. Michael Hall 1,2,3,4,t,** and Helena Power 1,+ \\ 1 Department of Management, Marketing and Entrepreneurship, University of Canterbury, Christchurch, \\ New Zealand; hele.power@gmail.com \\ 2 School of Business and Economics, Linneaus University, Kalmar, Sweden \\ 3 Department of Geography, University of Oulu, Oulu, Finland \\ 4 School of Hospitality and Tourism, University of Johannesburg, South Africa \\ * Correspondence: michael.hall@canterbury.ac.nz \\ + These authors contributed equally to this work.
}

\begin{abstract}
The concept of a Social License to Operate (SLO) has become increasingly important in the sustainability literature in recent years. Having its origins in the business discourse of the mining industry with respect to limiting opposition to mining projects, the notion of a social contract above and beyond legal requirements has since become applied across a number of different industries. Despite the concepts adoption confusion exists over the practices and outcomes of SLO, and particularly the nature of engagement. Given this situation it is surprising that not more attention to the role of marketing, and social marketing in particular, in operationalizing the concept. The paper discusses the potential of social marketing to contribute to SLO. Economic, political and social relations are complex in SLO and exchange is intricate in such relational environments. A community-based social marketing orientation is proposed as a means to improve exchange relations and enhance engagement. Seven models of SLO related social marketing models are discussed with community-based social marketing and adaptive co-marketing models being regarded as the most positive for the achievement of an SLO. Potential barriers to adoption of these approaches are noted.
\end{abstract}

Keywords: adaptive co-marketing; social marketing; community-based social marketing; social license to operate; community engagement; corporate social responsibility; marketing strategy

\section{Introduction}

The concept of a social license to operate (SLO) has drawn considerable attention in the academic literature on sustainability in recent years. The term is used to suggest that a "social contract" exists between businesses, often with a project that has significant environmental change associated with it, and the various communities of interest that are or will be affected by the project. While companies are required to abide by legal permits, regulation and licence, SLO is the less tangible aspect of social acceptance, which ensures a company is not at risk or, at least, reduces the corporate risk of community conflict or protests with its projects and/or products [1-3]. It has been suggested that the application of SLO is meant to encapsulate particular activities, ideals and values, that allow for successful business operations [4]. Although the exact nature of what is required for an SLO varies between cultures, locations, political settings and operations, there is a degree of agreement that it involves the development and maintenance of transparency and trust in stakeholder relations in order to provide of a voluntarily given exchange between companies and communities. For a company this exchange provides the "license" to undertake its activities, for the affected communities the exchange may have a range of tangible, e.g. infrastructure provision, sponsorships, recognition of sacred sites; or more intangible returns, e.g. cultural respect, 
guaranteed participation in consultation processes, development of partnership arrangements. Significantly, the SLO concept has evolved over time to also be understood as a strategic management tool that focuses on the socio-political rights and responsibilities of a company and has spread to other industries beyond its origins in mining and other extractive industries [5].

It has been suggested that SLO has gained traction as a concept because it is generally understood by both business and their various stakeholders and communities of interest [6-7]. While this may be the case, the reality of SLO lies in the recognition that the need for a SLO did not come from the "goodness of the corporate heart", but instead from the actual or potential objection or rejection of business projects and products by communities [2] (p. 318). The adoption of SLO therefore provides companies with the opportunity to not only prevent rejection by communities, and their potentially significant economic and reputational costs, but also to claim compliance or legitimacy without the approval of governments or legal bodies that enforce regulations $[2,8]$. SLO is therefore a significant mechanism for managing economic and reputational risk through formal and informal corporate actions [3, 9-14], while it has been claimed that companies that promote SLO have improved competitiveness and corporate reputation, ongoing resource access, experience reduced regulation, strengthened stakeholder relationships and a more positive workforce [11, 15-16].

Nevertheless, while there is substantial recognition of the value of SLO and what it should entail the criteria for defining the SLO "remain relatively murky" [4] (p. 63). Numerous studies recognize that SLO should reflect a company's best practices but then do not go into any depth of what those practices are or should be [17-21]. This article argues that a social marketing perspective has potential to shed considerable light on SLO and, in particular the role of exchange and social capital in affecting relations between companies and different communities of interest. In particular, social marketing may be able to shed light on processes and outcomes in SLO as well as improving engagement with communities.

\section{The Concept of Social License to Operate}

Although the exact origins of the term are unclear, it is generally agreed that the concept is connected to the notion of the social contract that allows a company to act responsibly in relation to its stakeholders and the wider public and therefore operate successfully in society [22-24]. The first recorded reference to SLO comes from a 1996 Paper Industry Manufacturing Association Magazine article [25], which proposed that the paper industry needed to maintain environmental standards beyond that set by government in order to obtain an SLO from the public for their operations. Nevertheless, many articles credit Jim Cooney, a Canadian mine executive for coining the term in relation to the need of the mining industry to develop better relations with communities so as to be able to reduce opposition to mining even when the company had met its legal requirements $[2,5,6$, 11, 13, 24, 26-27]. The term was simultaneously being applied to mining companies in Australia, where the concept was picked up by the Western Australian Technology \& Industry Advisory Council, in a report on Western Australia's Minerals and Energy Expertise [28]; as well as in reference to the operation and expansion of multinational companies in Latin America and the pressures they faced in being "good environmental actors" [29].

Since the late 2000s the term has come to be increasingly used in business discourse as well as the academic literature. Table 1 shows the number of journal articles in the Scopus database with "social license to operate" in their title, abstract or keywords. The first listing of the term in a journal article was in 2004. At the time of analysis in late 2016 forty papers had already used it. The majority of SLO research identified in the Scopus search had been conducted in or related to developing countries although the vast majority of researchers were located in Western universities. 
Table 1. Growth of SLO in the academic literature 2004-2016.

\begin{tabular}{cc}
\hline Year & $\begin{array}{c}\text { Number of journal articles with “Social License to } \\
\text { Operate" in their title, abstract or keywords }\end{array}$ \\
2016 & 40 \\
2015 & 21 \\
2014 & 37 \\
2013 & 13 \\
2012 & 5 \\
2011 & 5 \\
2010 & 6 \\
2009 & 7 \\
2008 & 1 \\
2007 & 1 \\
2006 & 3 \\
2005 & 2 \\
2004 & 1 \\
\hline
\end{tabular}

${ }^{1}$ Scopus database search undertaken 27 November

The adoption and growth of the concept can be connected to several related trends. First, the growing significance of the environment as political and consumer issues, in which opposition to a company can be voiced both at a specific operational level, e.g. preventing a mine going ahead or forest being clearfelled, or at a product level, e.g. organised boycotts of specific products or even products along a supply chain. Very importantly such opposition has become intermistic in that environmental or human rights issues, for example, are no longer framed as being a concern within a country, but have become concerns of citizens and consumers in other countries, who may take action against companies if they perceive behaviours to be wrong, and even if they have fulfilled their legal requirements [30-31]. Second, changes in in social values, that reflect the growth of political consumerism and concerns over various rights, have gone hand-in-hand with the growth of the global civil sector [3]. Third, the globalization of consumer concern over corporate activities is interrelated to the changes in communication technologies, especially the Internet, that provides various communities to voice concerns over corporate activities [6].

Many of the SLO characteristics are related to Corporate Social Responsibility (CSR) discourse. Stakeholder engagement is a prominent aspect of both CSR and SLO, however, it is widely emphasised that SLO should be practiced in a stakeholder-centric manner [32]. Edwards and Trafford suggest that the fundamental difference between CSR and SLO is that CSR is "top-down", with the company recognising the issues, whereas SLO is "bottom-up", with issues being identified by the community and stakeholders [16]. However, this approach, as with Moffat and Zhang's arguments that SLO proactively considers the concerns a community has towards a project that has the ability to delay or forbid an operation from taking place, and that CSR is reactive rather than proactive [33], is overly simplistic. Instead, what is significant with the concept of a SLO is that it is highly relational and, as will be discussed in more detail below, emphasises the importance of exchange. The nature of social and economic relations is that they are highly dynamic and SLO arguably not only builds and maintains the support from communities and stakeholders that business operations require but, and what is fundamentally different from CSR, frames the power and other socio-economic relationships between businesses and communities and what makes business activity legitimate over time in particular locations [12, 13].

Black emphasises that in order to build and maintain a company's SLO the company is required to play a constructive role in sustainable community development [3], however the level of involvement is not clearly established. This is also apparent in other studies that argue that an approved SLO requires free, prior and informed consent from a local community [19], with Wilburn and Wilburn further suggesting that the level of consent or who the stakeholders are is not clearly 
established or determined [7]. Due to the relational nature of SLO a number of authors highlight that once a SLO is obtained the company must continue to reassess the terms of their SLO because the operational environment is evolving throughout the lifecycle of a project [3, 23, 27]. The SLO should, therefore, continuing to be flexible in nature and accommodate potential changes in social dynamics. Indeed, it has been argued that one of the pitfalls of the lack of clear definition of SLO, even given its increasing use in business and sustainability discourse, is that the focus of SLO has become short term goal orientated, resulting in a lack of clarity concerning what a SLO must entails given its relational nature [4].

In order to achieve a SLO a company must be considerate of the varying expectations conveyed by different social groups, the interactions the company has with communities and how they utilise the influence of stakeholders [14]. Moffat and Zhang suggest that SLO requires four key characteristics to be present, including procedural fairness; distributional fairness; good governance; and trust [33-35]. In contrast, Thomson and Boutilier [27] who, expanding on Corvellec's [36] spectrum approach [37], proposed that there were different levels of social licence with boundary criteria between them. The suggested levels are withdrawal, acceptance, approval and psychological identification, while the boundaries were legitimacy, credibility and full trust. Boutilier and Thomson further refined the hierarchy in a study that focused on Mexico and Australia, with the overall level of SLO being measured through four independent factors of institutionalised trust, socio-political legitimacy, interactional trust and economic legitimacy [9, 26]. As an operation developed, legitimacy, followed by credibility on the behalf of local stakeholders would allow acceptance and then the approval of the operation to go ahead $[5,9,26]$. If a company is seeking to establish a SLO then it must therefore focus on building trust and exercise transparency in order to achieve the highest level of the hierarchy, co-identification [32, 37-39].

Trust is defined by Moffat and Zhang as "having confidence that the behaviour of a outgroup ... will match expectations of the trust holder...to trust someone or an outgroup is to expect that they will not exploit one's vulnerability and even seek to cooperate" [32] (p. 62). Trust is regarded as "integral to all decision-making processes, impacting on people's perceptions of risk, influencing the way they approach engagement opportunities" [14] (p. 192), subsequently influencing the level of support expressed by the stakeholders [26]. It is believed that a "firm might increase its chance of gaining the communities' trust by establishing and maintaining communication with communities... by acting transparently" [39] (p. 98). Being transparent can build trust on a long-term basis and fairness among people within the local community [18, 38]. Parsons, Lacey and Moffat found that stakeholders described trust as a critical aspect of SLO and sits alongside reputation, transparency, credibility, respect, honesty and relationships [20]. The level of trust expressed by a community is often established through community engagement initiatives and the flow on effects that the involvement of these initiatives and the legacy of previous activities and relationships [14]. Once complete trust is expressed towards a project the local community will begin to co-identify with the project, suggesting that the company has meet the current expectations of the community [40].

Stakeholders and communities are usually regarded as central to establishing a SLO, although their capacity to influence is not clearly understood $[3,7,10,14,31,40]$. However, there is significant divergence in the literature as to how they should be defined and what role they play $[8,41)$. Boutilier et al. [5] recognised stakeholders as groups and individuals who are potentially affected by a project, or those that can impact a project, whereas Bice recognises SLO stakeholders as "affected local communities, NGOs and community organisations, other companies operating within the same industry or geographical region, governments, local businesses, landholders and indigenous groups, regulators and industry bodies" [4] (p. 68). Wilburn and Wilburn [7] (p. 8) further suggest that "customers, suppliers and partners, as well as social political, and government entities" are also included. Yet there is considerable divergence as to how engagement should take place $[14,38$, 42-44]. Nevertheless, It is suggested that stakeholders who experience greater engagement and dialogue on behalf of a company will be more inclined to see the SLO as credible and want to enforce it [32, 45-48]. Hall recognised engagement as a central part of SLO in her study of wind farm 
development, as it was a way to increase the acceptance and approval of the wind farm over the span of its development [49-50]. On the other hand, Owen and Kemp argue that the application of SLO is more about reducing opposition to industry than it is about engagement for long term development [8].

The different perspectives on understanding SLO and how to engage different communities of interest raise fundamental issues with respect to the operationalization of the concept. Perhaps surprisingly there is little discussion in the SLO literature on the potential role of marketing in SLO. This is perhaps unexpected not only because of the substantial literature that exists on marketing and sustainability, and marketing and CSR, but also because of the significance of social marketing as a marketing sub-discipline that has an extremely strong tradition of community engagement and change. The next section therefore focuses on social marketing before the article discusses how insights from social marketing can be used to better frame SLO.

\section{Social Marketing}

Social marketers deal with situations that are intricate [51] and complex [52]. Social marketing utilises marketing techniques and methods to promote behavioural change in a target audience to engender social good. The concept of social marketing was introduced by Kotler and Zaltman in 1971, referring to the application of marketing principles and methods to "the design, implementation, and control of programs calculated to influence the acceptability of social ideas" [53] (p. 5). Social marketing has received substantial attention from scholars in marketing and related disciplines and has generally been used to promote behavioural change with respect to health, the environment and well-being [54-62).

Although traditionally associated with government and non-government organisations the concept has expanded to incorporate the corporate social marketing concept, which is defined as an activity that "uses business resources to develop and/or implement a behavior change campaign intended to improve public health, safety, the environment, or community well-being" [58] (p. 111). Changes in notions of public governance has seen governments and public agencies increasingly work in partnerships with the private sector and non profit organisations [58-59, 63]. Many social marketing programs undertaken in less developed countries also utilise private sector marketers and NGOs in order to increase their effectiveness [64].

At the same time as governments have sought to utilise businesses and NGOs to achieve social marketing objectives, many companies are increasingly supporting social causes while targeting their business goals [58, 63]. Although not undertaken under the notion of SLO, business support for social issues has evolved beyond narrowly defined philanthropic and volunteering initiatives to encompass more mutually beneficial, long-term partnerships aimed to accomplish strategic business and societal goals $[58,63,65]$. Lefebvre [64, 66], for example, argues that social marketing needs to move beyond a focus on non-profit and public entities to encompass all actors in the market system, especially given that lasting success in influencing behavioural change requires strategic, long-term partnerships between government agencies, NGOs, and private companies [62-63, 67].

Community-based social marketing (CBSM) is a sub-field of social marketing that puts a great emphasis on the social marketing process being conducted in cooperation with the communities in which behaviour change is desired. Examples of tools used in CBSM include gaining commitment from participants, prompts (such as visual and verbal aids), the use of norms, a well developed communication program to educate and persuade, and the use of incentives [68-71]. There is growing interest in the role of CBSM in CSR. CBSM is regarded as complimentary to regulatory approaches and can help encourage voluntary behaviour change, especially given a focus on appropriate communication and engagement strategies [72-73]. The emphasis on communities in CBSM fits empathetically with the importance of responsibility in CSR [74] and the notion of community stakeholders embraced by much of the SLO literature. Yet surprisingly, there is currently very little formal connection between CSM and SLO. Hine, Crofts and Becker regard social marketing, and CBSM in particular, as a way of developing a social license for particular land stewardship policies [75]. However, this perhaps is, as they suggest, "a new paradigm" [75]. 
Nevertheless, there is a substantial weight of evidence that community engagement, to which social marketing can contribute, can lead to longer-term enhanced firm legitimacy [72]. However, as noted above, one of the significant weaknesses of SLO is the process by which communities may be engaged.

\section{Social Marketing, Social Capital and Social License to Operate}

Three components are central to social marketing: long-term focus; a consumer or customer orientation; and exchange (the market) [76]. The long term focus arises because behaviour change takes time and because social marketing is strategic. Consumer orientation arises because of the need to be aware of and listen to the needs of the consumer, whether the consumer is here regarded as target individuals, private or public organizations or specific segments, in order to achieve public good. Exchange is a critical element of the marketing concept. A key point of social marketing is that as well as markets for products and services there are markets for behaviors and ideas where people make choices about what behaviours they want to adopt, often by considering various alternative behaviors, choices, models, and experiences $[64,66]$. However, in social marketing the notion of exchange is more than just economic and also includes social exchange. The content of exchange can be utilitarian (economic and relatively tangible), symbolic (psychological, social and intangible) or a combination of both utilitarian and symbolic, in fact given the embeddedness of economic exchange in identity and social practices most exchanges are mixed [51, 52, 77-79].

Markets fail. Market failure occurs when the exchange process reduces societal well-being. The outcomes of exchange can be beneficial to the parties involved (positive externality) or impose costs (negative externality). Social marketing arguably exists within an environment of market failure, brought about by externalities [51]. From an SLO perspective a negatively externality exists when others who are not formally part of the exchange are negatively affected by the process or outcome of this exchange, or where a conscious or formal exchange has not even been established. This latter point is particularly relevant as SLO implies the inclusion of all those who see themselves affected by a company's actions. Achievement of an SLO represents an exchange by which communities and stakeholders provide consent for a company to undertake specific activities and actions, and a company has provided intangible (e.g. community and stakeholder consultation, transparency) and/or tangible (e.g. charitable donations, community welfare, corporate giving, donations in kind, grants, local recruitment, pollution control, volunteering, waste minimization) returns. SLO is therefore grounded in reciprocity. Importantly, encouragement to participate in a reciprocal exchange for granting an SLO needs to be directed at both companies who require a license, so as to overcome opposition from affected stakeholder for example, as well as communities and stakeholders. In light of the identified role of trust in SLO and as a moderating influence on the effects of market failure it is therefore significant that the fostering of trusting and mutually giving relationships has been identified as a fundamental aim of social marketing [51].

Much attention has been given to the significance of social capital in SLO. Social capital can be regarded as "the goodwill that is engendered by the fabric of social relations and that can be mobilised to facilitate action" [80] (p. 17). The notion of goodwill reflects the centrality of trust as part of the norms of reciprocity with a series of networks of social associations and relationships [81]. Given that networks provide actors with the capacity to mobilize action and derive benefits social capital is therefore appropriable [51]. However, in order to do so, actors must establish, develop and maintain networks through on-going trust building measures in order for social capital to remain productive [51]. With respect to SLO it has been suggested that moving from legitimacy, through credibility, to full trust between companies and stakeholders, is a process of building and balancing the social capital in a company's stakeholder network which is derived from structural, relational and cognitive sources [27]. Nevertheless, it should be noted that some bonding forms of social capital, such as strong social norms, may have negative consequences for other forms of social capital generation (what may be described as bridging capital, i.e. the weak ties between acquaintances who may provide new information or perspectives for one another and who share a distinct social identity as colleagues, neighbors or members; but who do not usually provide 
emotional support) [82] as it means they may be excluded. When such a situation occurs new ideas may be hindered in being introduced into the social structure. In terms of achieving a SLO therefore it is not social capital per se, but the right balance between the bonding and bridging forms of social capital for its effective generation over time that will help a company achieve an SLO.

From a marketing perspective bridging forms of social capital can provide opportunities for the marketing of information [82-85], e.g. via word of mouth. In health related social marketing, having a local infrastructure of social ties available in a community has been found to predict the diffusion of available health care services in that community [86-87]. Bonding forms of social capital can provide opportunities to social marketers to take advantage of the presence of social norms in influencing behaviour, e.g. in encouraging recycling or water usage in hotels [78, 88], especially when embedded social practices are tackled as well [77, 79, 89]. However, if bonding forms dominate social capital formation social marketing can face difficulties in informing an audience about a social issue [51]. For example, it has been found that parents' attitude toward talking about drugs with their child mediated the effects of antidrug-specific social capital on targeted parent-child drug related communication [90], or the role of social norms in religious congregations and the social construction of HIV/AIDS risks and prevention [91]. In both cases, conformity and structural relations affect information flows. Effective CSM therefore requires mechanisms to counter threats of exclusion and the benefits of networks to individuals as a result of challenging social norms.

Social capital theory also provides insights into a significant issue for SLO which is how to market to an individual or organisation that has no incentive to participate in an exchange. From a social marketing perspective a way to approach this issue is in terms of the provision of access to network benefits [51, 84]. Networks carry economic, social and other benefits. A person can either participate in a network and comply with its norms or continue existing behavior of non-participation and lose the network and its benefits. In a social marketing environment what is costing the individual to buy the product is the opportunity cost, the sacrifice required, to obtain an individual's first preference. Therefore, in order to make the exchange (to join the network) less costly, the behavior change needs to appear more positive than the previous behavior of non-participation and also convey the impression that the loss of network benefits will be large [51].

\section{Social Marketing and Engagement in SLO}

One of the significant weaknesses of the SLO literature is a failure to effectively delineate the processes by which engagement occurs in the development of an SLO and the outcomes. In the case of the latter a successful SLO is usually assumed to be that a project can go ahead or that a product can be marketed and sold without opposition. However, this is an extremely narrow view of an SLO. A successful SLO should be understood as the agreement between a company and community interests with respect to a particular course of commercial action. This may be for a project to go ahead in a particular form, which may have been modified as a result of community engagement, but equally there may be an agreement not to pursue the project at a given point in time but the level of trust between the company and community interests that it may be able to go ahead in the future or that the best commercial course of action is not to continue. In other words the outcome of the social contract between company and communities can take several forms and it is the strength of the contract (the SLO) that is most significant over time rather than a particular identifiable output, such as corporate gifts. From a CBSM perspective such outputs from the SLO process can also be regarded as a form of incentive by which behaviours are changed in relation to the SLO. However, Table 2 does indicate a number of incentives from the SLO process that may be indicative of the exchange between a company and communities of interest in enabling a project to go ahead. 
Table 2. Exemplars of incentives for an SLO process identified in the literature as deriving from company actions.

\begin{tabular}{|c|c|}
\hline Category & Examples \\
\hline $\begin{array}{l}\text { Adoption of international } \\
\text { standards }\end{array}$ & $\begin{array}{l}\text { - Amnesty International human rights principles for companies } \\
\text { - Global Reporting Initiative (GRI) Sustainability reporting } \\
\text { guidelines } \\
\text { - UN Global Compact } \\
\text { - World Bank Group performance standards on social and } \\
\text { environmental sustainability } \\
\text { - AA1000 stakeholder engagement standard }\end{array}$ \\
\hline Generic corporate giving & $\begin{array}{l}\text { - } \text { charitable donations } \\
\text { - } \text { dommunity welfare } \\
\text { - grants } \\
\text { - } \text { volunteering } \\
\text { - general education }\end{array}$ \\
\hline Employment and workforce & $\begin{array}{l}\text { - local recruitment and employment } \\
\text { - } \text { specific project related education and training } \\
\text { - diversity and equal opportunity } \\
\text { - } \text { health and safety } \\
\text { - } \text { accompensation and rewards }\end{array}$ \\
\hline Social initiatives & $\begin{array}{ll}\text { - } & \text { infrastructure provision } \\
\text { - } & \text { education } \\
\text { - } & \text { health } \\
\text { - } & \text { provision for after project is finished } \\
\text { - } & \text { sport }\end{array}$ \\
\hline $\begin{array}{l}\text { Project specific environmental } \\
\text { measures }\end{array}$ & $\begin{array}{ll}\text { - } & \text { cleanliness } \\
\text { - } & \text { energy management } \\
\text { - } & \text { improved production processes } \\
\text { - } & \text { pollution control } \\
\text { - } & \text { waste management } \\
\text { - } & \text { water conservation } \\
\end{array}$ \\
\hline
\end{tabular}

However, the provision of certain outputs as part of the exchange between company and community provides only limited information about the nature of the engagement in a SLO and does not necessarily provide much guidance to the strength of the SLO over time. Instead there is a need to connect a more detailed understanding of engagement with the extent of SLO and the models by which exchange is sought.

\subsection{A Continuum of Social Marketing Models}

There is a continuum of social marketing models that involve consumers and communities in SLO processes in different and significant ways (Figure 1). The figure illustrates that there are different ways in which the relationships between companies and the communities of interest can inform the nature of an SLO. The various elements of the social marketing process are noted as well as identification of lead actors, spatial scope, and nature of engagement. The degree of collaboration and positive exchange over time between companies, professionals and community interests, and therefore the extent of an SLO, increases as you move from left to right. The nature of such engagement is described in more detail in Table 3 and is derived from the AA1000 Stakeholder Engagement Standard [92, 93]. 


\begin{tabular}{|c|c|c|c|c|c|c|c|}
\hline $\begin{array}{l}\text { Stages of the } \\
\text { social } \\
\text { marketing } \\
\text { process }\end{array}$ & $\begin{array}{l}\text { Denial of } \\
\text { SLO } \\
\text { (project) }\end{array}$ & $\begin{array}{l}\text { Denial of } \\
\text { SLO } \\
\text { (product) }\end{array}$ & $\begin{array}{l}\text { Firm- } \\
\text { centric } \\
\text { CSR } \\
\text { model }\end{array}$ & $\begin{array}{l}\text { Traditional } \\
\text { marketing } \\
\text { model }\end{array}$ & $\begin{array}{l}\text { Traditional } \\
\text { social } \\
\text { marketing } \\
\text { model }\end{array}$ & $\begin{array}{l}\text { Community- } \\
\text { based social } \\
\text { marketing } \\
\text { (CBSM) }\end{array}$ & $\begin{array}{l}\text { Adaptive } \\
\text { co- } \\
\text { marketing } \\
\text { model }\end{array}$ \\
\hline $\begin{array}{l}\text { Problem } \\
\text { identification }\end{array}$ & $\dot{\varphi}$ & $\ddot{l}$ & $\checkmark$ & $\checkmark$ & $\checkmark \dot{1}<--i$ & 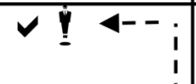 & $\checkmark \dot{1}<--i$ \\
\hline $\begin{array}{l}\text { Conduct } \\
\text { research }\end{array}$ & & & & $\checkmark$ & $\checkmark$ & $\checkmark \stackrel{1}{1}$ & $\checkmark \dot{y}$ \\
\hline $\begin{array}{l}\text { Segment \& } \\
\text { target } \\
\text { market }\end{array}$ & & & & $\checkmark$ & $\begin{array}{l}1 \\
1 \\
1 \\
1\end{array}$ & $\begin{array}{l}1 \\
1 \\
1 \\
1 \\
1\end{array}$ & $\checkmark$ \\
\hline $\begin{array}{l}\text { Establish } \\
\text { goals \& } \\
\text { objectives }\end{array}$ & & & $\checkmark$ & $\checkmark$ & $\begin{array}{l}1 \\
1 \\
1 \\
1\end{array}$ & 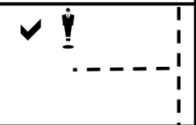 & $\checkmark \dot{\varphi}$ \\
\hline $\begin{array}{l}\text { Marketing } \\
\text { strategy }\end{array}$ & & & $\checkmark$ & $\checkmark$ & $\checkmark$ & $\begin{array}{l}1 \\
1 \\
1 \\
\end{array}$ & 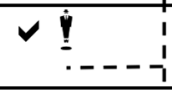 \\
\hline $\begin{array}{l}\text { Implement } \\
\text { program }\end{array}$ & & & $\checkmark$ & $\checkmark$ & $\checkmark$ & $\begin{array}{l}1 \\
1 \\
1\end{array}$ & $\checkmark \grave{I}$ \\
\hline $\begin{array}{l}\text { Evaluation \& } \\
\text { monitoring }\end{array}$ & & & & $\checkmark$ & $\begin{array}{l} \\
\\
\end{array}$ & $\begin{array}{lrr}\checkmark & 1 \\
& . & \ldots\end{array}$ & $\checkmark \dot{y}$ \\
\hline Lead actors & $\begin{array}{l}\text { Impacted } \\
\text { community }\end{array}$ & $\begin{array}{l}\text { Consumers } \\
\& \text { interest } \\
\text { groups }\end{array}$ & Managers & Managers & \begin{tabular}{l|} 
NGOs, \\
government
\end{tabular} & $\begin{array}{l}\text { Community } \\
\text { groups, } \\
\text { Managers, } \\
\text { target } \\
\text { markets }\end{array}$ & All \\
\hline Scope & Narrow & Broad & Variable & Variable & Narrow & Narrow & $\begin{array}{l}\text { Variable } \\
\text { (initially } \\
\text { narrow but } \\
\text { expanding } \\
\text { over time) }\end{array}$ \\
\hline Engagement & $\begin{array}{l}\text { Passive, } \\
\text { Monitor }\end{array}$ & $\begin{array}{l}\text { Passive, } \\
\text { Monitor }\end{array}$ & $\begin{array}{l}\text { Monitor, } \\
\text { advocate } \\
\text { \& inform }\end{array}$ & Consult & $\begin{array}{l}\text { Consult \& } \\
\text { transact }\end{array}$ & Involve & $\begin{array}{l}\text { Collaborate, } \\
\text { Empower }\end{array}$ \\
\hline
\end{tabular}

Note: Check marks ( $\checkmark$ )indicate professionals, people $(\stackrel{\dot{\gamma}}{)})$ represent public/community participants, solid arrows indicate the flow of actions, dashed arrows indicate the iterative aspect of adaptive marketing processes

Figure 1. A continuum of social marketing models showing their relationship to SLO and engagement.

Table 3. Levels and methods of engagement.

\begin{tabular}{cll}
\hline $\begin{array}{c}\text { Level of } \\
\text { Engagement }\end{array}$ & Characteristics & Methods \\
\hline Passive & No active communication & $\bullet$ Stakeholder concern expressed \\
& & through protest \\
& & $\bullet$ Letters \\
& & $\bullet$ Media \\
Monitor & One-way communication: between & $\bullet$ Media and Internet tracking \\
& stakeholder and organisation & $\bullet$ Second-hand reports from other \\
& & stakeholders possibly via targeted \\
& & interviews. \\
Advocate & One-way communication: between & $\bullet$ Pressure on regulatory bodies \\
& stakeholder and organisation & \\
\hline
\end{tabular}




Inform $\quad$ One-way communication between
organisation and stakeholder, there is
no invitation to reply

Transact Limited two-way engagement: setting and monitoring performance according to terms of contract

Consult Limited two-way engagement: organisation asks questions, stakeholders answer

Negotiate

Involve

Collaborate

Empower

New forms of accountability; decisions delegated to stakeholders; stakeholders play a role in shaping organisational agendas
- Other advocacy efforts through social media

- Lobbying efforts

- Bulletins and letters

- Brochures

- Reports and websites

- Speeches, conference and public presentations

- 'Public- Private partnerships'

- Private Finance Initiatives

- Grant-making

- Cause-related marketing.

- Surveys

- Focus groups

- Meetings with selected

stakeholder/s

- Public meetings

- Workshops

- Collective bargaining with workers through their trade unions

- Multi-stakeholder forums

- Advisory panels

- Consensus building processes

- Participatory decision-making processes

- Focus groups

- Online engagement tools

- Joint projects

- Joint ventures

- Partnerships

- Multi-stakeholder initiatives

- Online collaborative platforms

- Integration of stakeholders into governance, strategy and operations of the organisation / project

${ }^{1}$ Derived from AccountAbility 2015.

The first two examples (denial of SLO) are best described as non-marketing models as they emphasise that there is no social contract between either a community impacted by a proposed or actual project, or between consumers and a product $[94,95]$. This model is marked by extremely limited engagement between company and stakeholders. The third example is that of a firmcentric approach to CSR which extremely top-down in orientation [17]. Although such approaches may be undertaken with good intentions and are strategic from a corporate perspective they are often not 
tied in to detailed market analysis and research nor are extensively monitored or evaluated, in contrast to a traditional marketing model.

As noted above social marketing utilizes a number of elements of the traditional marketing model but while adopting many of the tools of marketing does so for the public good. Therefore, there is a much stronger level of community and stakeholder involvement in problem identification in social marketing. This approach is taken further in a community-based social marketing approach which provides for an even stronger role for community interests in terms not only of problem definition but also research conduct, and establishing the goals and objectives for any intervention [96]. The community-based social marketing model also has significant overlap with participatory action research approaches where issue definition process begins with the interests of participants, who then work in collaboratively with professional researchers through all steps of the research process to find solutions to community and sustainability problems [96-99]. The importance of participatory research for SLO is also noted by a number of authors as an important means of obtaining meaningful community engagement with extractive industries [18, 100-102). The final model is an extension of such an approach but adopts the notion of adaptive co-marketing so as to emphasise that the process extends over time, such as the life of a project, and draws in ideas of adaptive management [103-106] to emphasise that this is a strategic marketing process the recommendations of which are iteratively evaluated and revised by the company and all community interests in order to improve outcomes. By emphasising the interactive feedback elements of the model it may be possible to enlarge the range of stakeholders involved in the process.

\section{Conclusions}

The concept of Social License to Operate has received increasing attention in research literature as well as becoming an important component of the business discourse of sustainability. However, there have been substantial difficulties with its operationalization with substantial confusion over how it might be achieved, indicators, and engagement. This article has highlighted the potential of a social marketing approach to improving both the understanding of SLO and identifying ways by which it may be accomplished. It has provided an account of different marketing models of SLO, including what may be described as non-marketing approaches, and has suggested that community-based social marketing and adaptive co-marketing approaches over the greatest potential to achieve an SLO.

Nevertheless, even though models identify some of the tools, strategies and approaches that may be used for SLO it does not mean they will necessarily be adopted. Several reasons can be provided. First, do companies possess the necessary skill sets to enable effective engagement in achieving SLOs. Community-based social marketing and adaptive co-marketing will often require trans-disciplinary teams capable of handling different research paradigms and methods and being able to effectively translate them between different stakeholders and corporate units. Participatory methodologies will often be crucial for meaningful deliberative and inclusive consultation. In addition, various communities of interest may also not possess the necessary skills sets to easily engage in the relational exchange of SLO whether this be because of the knowledge base, or cultural and structural reasons, such as power structures and participatory traditions. In such cases the development of such skill sets via education and capacity building would become part of the adaptive co-marketing process.

Second, for various reasons it needs to be acknowledged that a company that is initially seeking an SLO for its products and/or operations may eventually not be willing to engage in such processes given the perceived financial and reputational costs that may be involved. An SLO often takes time to achieve, especially given the complex political and socio-economic environments surrounding many projects, whether they be in the extractive industries or in the construction of NIMBYs such as wind turbines or transmission lines. Financial limitations or shareholder demands may serve to limit company capacities to engage with communities and focus its risk management strategies on more short-term outcomes [108]. 
Finally, achievement of an SLO requires a supportive set of corporate values and business orientation [109]. An SLO is not a magic bullet. It requires time and commitment to be achieved and a high level of engagement. The degree of transparency, trust and engagement required may not fit with a company's orientation and values. Particularly as it requires synergies between the demands of shareholders and community stakeholders that can be extremely hard to achieve. It is possible that successful engagement by a company with SLO in relation to specific products and/or projects and the presence of the skills required within a business may lead to the development of an SLO orientation over time, but the length of time over which the concept has existed means that this is an outcome of the relational exchange of SLO to be looked for in the future. The successful achievement of an SLO will not only require communities to adapt and change but for corporations to change their orientation as well.

Author Contributions: C.M.H. and H.P. conceived and designed the paper, conducted the literature review, analyzed the data and wrote the paper.

Conflicts of Interest: The authors declare no conflict of interest.

\section{References}

1. Melé, D., Armengou, J. Moral legitimacy in controversial projects and its relationship with social license to operate: A case study. J. Bus. Ethics 2016, 136, 729-742.

2. Syn, J., The social license: empowering communities and a better way forward. Soc. Epistemol. 2014, 28, 318-339.

3. Gehman, J., Thompson, D.Y., Alessi, D.S., Allen, D.M., Goss, G.G. (2016). Comparative analysis of hydraulic fracturing wastewater practices in unconventional shale development: Newspaper coverage of stakeholder concerns and social license to operate. Sustainability 2016, 8(9), 912.

4. Bice S. What gives you a social licence? An exploration of the social licence to operate in the Australian mining industry. Resources 2014, 3, 62-80.

5. Boutilier, R.G., Black, L., Thomson, I. From metaphor to management tool: How the social license to operate can stabilise the socio-political environment for business. In International Mine Management 2012 Proceedings. Australian Institute of Mining and Metallurgy: Melbourne, Australia, 2012, pp. 227-337.

6. Bice, S., Moffat, K. Social licence to operate and impact assessment. Impact Assess. Proj. Apprais. 2014, 32(4), 257-262.

7. Wilburn, K.M., Wilburn, R. Achieving social license to operate using stakeholder theory. J. Int. Bus. Ethics 2011, 4(2), 3-16.

8. Owen J., Kemp D. Social licence and mining: a critical perspective. Resour. Policy 2012, 38, 29-35.

9. Boutilier, R.G., Thomson, I. Modelling and measuring the SLO, invited paper presented at The Social License to Operate. Centre for Social Responsibility in Mining, University of Queensland, Brisbane, July 15 2011, http://www.socialicense.com/publications/Modelling\%20and\%20Measuring\%20the\%20SLO.pdf.

10. Holley, E.A., Mitcham, C. The Pebble Mine Dialogue: A case study in public engagement and the social license to operate. Resour. Policy 2016, 47, 18-27.

11. Joyce, S., Thomson, I. Earning a social licence to operate: social acceptability and resource development in Latin America. Canadian Mining Metallurgical Bull. 2000, 93, 49-53.

12. Prno J. An analysis of factors leading to the establishment of a social licence to operate in the mining industry. Resour. Policy 2013, 38, 577-590.

13. Wilson, S.A. Corporate social responsibility and power relations: Impediments to community development in post-war Sierra Leone diamond and rutile mining areas. The Extractive Industries and Society 2015, 2, 704-713

14. Wilson, E. What is the social licence to operate? Local perceptions of oil and gas projects in Russia's Komi Republic and Sakhalin Island. The Extractive Industries and Society 2016, 3, 73-81.

15. Dare, M., Schirmer, J., Vanclay, F. Community engagement and social licence to operate. Impact Assess. Proj. Apprais. 2014, 32(3), 188-197.

16. Gunningham, N., Kagan, R.A. Thornton, D. Social license and environmental protection: Why business goes beyond compliance. Law Soc. Inq. 2004, 29, 307-341

17. Edwards, P., Trafford, S. Social licence in New Zealand-what is it?, J. Royal Society New Zealand 2016, 46, 3-4, 165-180 
18. Heikkinen, H.I., Lépy, É., Sarkki, S., Komu, T. Challenges in acquiring a social licence to mine in the globalising Arctic. Polar Record 2016, 52, 399-411.

19. Michell, G., McManus, P. Engaging communities for success: social impact assessment and social licence to operate at Northparkes mines, NSW. Aust Geogr. 2013, 44, 435-459.

20. Parsons, R., Lacey, J., Moffat, K. Maintaining legitimacy of a contested practice: How the minerals industry understands its 'social licence to operate'. Resour. Policy 2014, 41, 83-90.

21. Mayes, R. A social licence to operate: corporate social responsibility, local communities and the constitution of global production networks. Global Networks 2015, 15(s1), S109-S128

22. Shocker, A.D., Sethi, S.P. An approach to incorporating societal preferences in developing corporate action strategies. California Manag. Rev. 1973, 15(4), 97-105.

23. Florini, A. The Public Roles of the Private Sector in Asia: The Emerging Research Agenda. Paper for Collaboration Among Government, Market, and Society Forging Partnerships and Encouraging Competition, Fudan University, Shanghai, China, May 25-27, 2013.

24. Boutilier, R.G. Frequently asked questions about the social licence to operate. Impact Assess. Proj. Apprais. 2014, 32, 263-272.

25. Moore, W.H. The social license to operate. PIMA Magazine 1996, 78(10), 22-23.

26. Edwards, P., Lacey, J. Can't climb the trees anymore: social licence to operate, bioenergy and whole stump removal in Sweden. Soc. Epistemol. 2014, 28, 239-257.

27. Thomson, I., Boutilier, R.G. Social license to operate. In SME Mining Engineering Handbook; Darling, P. Ed.; Society of Mining Metallurgy and Exploration: Littleton, USA, 2011, pp. 1779-1796.

28. Algie, S. Western Australia's Minerals and Energy Expertise: How can it be optimised? Defining the Issues: A Background Paper. Western Australian Technology and Industry Advisory Council: Bentley, Australia, 1997

29. Gentry, B., Esty, D. Private capital flows: New and additional resources for sustainable development. Bridges to Sustainability: Business and government working together for a better environment. Yale FEES Bull. 1997, 101, 18-45.

30. Brueckner, M., Pforr, C. Global environmental issues. In Theory and Practice of Corporate Social Responsibility; Idowu, S.O., Louche, C. Eds.; Springer: Berlin, Germany, 2011, pp. 73-88.

31. Hall, C.M. Changing paradigms and global change: from sustainable to steady-state tourism. Tourism Recreation Research 2010, 35(2), 131-145.

32. Hall, N., Jeanneret T. Social licence to operate: an opportunity to enhance CSR for deeper communication and engagement. Corporate Commun. 2015, 20, 213-227.

33. Moffat, K., Zhang, A. The paths to social licence to operate: An integrative model explaining community acceptance of mining. Resour. Policy 2014, 39, 61-70.

34. Nelsen J.L. Social license to operate. Int. J. Mining Reclam. Environment 2006, 20, 161-162.

35. Moffat, K., Lacey, J., Zhang, A., Leipold, S. The social licence to operate: a critical review. Forestry 2016, 89(5): 477-488.

36. Corvellec, H. Arguing for a licence to operate: the case of the Swedish wind power industry. Corporate Commun. 2007, 12, 129-144.

37. Dowd, A.M., James, M. A social licence for carbon dioxide capture and storage: How engineers and managers describe community relations. Soc. Epistemol. 2014, 28(3-4), 364-384.

38. Jijelava, D., Vanclay, F. Social licence to operate through a gender lens: The challenges of including women's interests in development assistance projects. Impact Assess. Proj. Apprais. 2014, 32(4), 283-293.

39. Costanza, J.N. Mining conflict and the politics of obtaining a social license: Insight from Guatemala. World Development 2016, 79, 97-113.

40. Demuijnck, G., Fasterling, B. The social license to operate, J. Bus. Ethics 2016, 136, 675-685.

41. Prno, J., Slocombe, D.S., Exploring the origins of 'social license to operate' in the mining sector: perspectives from governance and sustainability theories. Resour. Policy 2012, 37, 346-357.

42. Nielsen, A.E. License to operate. In Encyclopedia of Corporate Social Responsibility; Idowu, S.O., Capaldi, N., Zu, L., Gupta, A.D. Eds.; Springer: Berlin, Germany, 2013, pp. 1585-1591.

43. Mayes, R., Pini, B., McDonald, P. Corporate social responsibility and the parameters of dialogue with vulnerable others. Organization 2013, 20, 840-859

44. Mayes, R., McDonald, P., Pini, B. 'Our' community: corporate social responsibility, neoliberalisation, and mining industry community engagement in rural Australia. Environment E Planning A 2014, 46, 398-413. 
45. Brueckner, M., Durey, A., Pforr, C., Mayes, R. The civic virtue of developmentalism: on the mining industry's political licence to develop Western Australia. Impact Assess. Proj. Apprais. 2014, 32(4), 315-326.

46. Greenall, D., Rovere, D. Engaging Stakeholders and Business-NGO Partnerships in Developing Countries: Maximizing an increasingly important source of value. Centre For Innovation in Corporate Responsibility, Ottawa, Canada, 1999.

47. Ruckstuhl, K., Thompson-Fawcett, M., Rae, H. Māori and mining: Indigenous perspectives on reconceptualising and contextualising the social licence to operate. Impact Assess. Proj. Apprais. 2014, 32(4), 304-314.

48. Hall, N., Lacey J., Carr-Cornish S., Dowd A-M. Social licence to operate: understanding how a concept has been translated into practice in energy industries. J. Cleaner Product. 2015, 86, 301-310.

49. Hall, N.L. Community corporate engagement on water resource impacts: opportunities for social licence to operate. Australian J. Water Resour. 2015, 19(2), 109-115.

50. Hall, N.L. Can the "social licence to operate" concept enhance engagement and increase acceptance of renewable energy? A case study of wind farms in Australia. Soc. Epistemol. 2014, 28(3-4), 219-238.

51. Glenane-Antoniadis, A., Whitwell, G., Bell, S.J., Menguc, B. Extending the vision of social marketing through social capital theory marketing in the context of intricate exchange and market failure. Mark. Theory 2003, 3, 323-343.

52. Bagozzi, R. Marketing and exchange. J. Mark. 1975, 39(October), 32-39.

53. Kotler, P.; Zaltman, G. Social marketing: An approach to planned social change. J. Mark. 1971, 35, 3-12.

54. Hastings, G. Social Marketing: Why should the devil have all the best tunes?. Butterworth-Heinemann, Oxford, UK, 2007.

55. Barr, S., Gilg, A., Shaw, G. 'Helping people make better choices': Exploring the behaviour change agenda for environmental sustainability. Applied Geog. 2011, 31, 712-720.

56. Carrigan, M., Moraes, C., Leek, S. Fostering responsible communities: A community social marketing approach to sustainable living. J. Bus. Ethics 2011, 100, 515-534.

57. Cismaru, M., Lavack, A.M., Markewich, E. Social marketing campaigns aimed at preventing drunk driving: A review and recommendations. Int. Mark. Rev. 2009, 26, 292-311.

58. Kotler, P., Hessekiel, D., Lee, N. Good Works! Marketing and Corporate Initiatives That Build a Better World...And the Bottom Line. Wiley: Hoboken, USA, 2012.

59. Kotler, P., Lee, N. Social marketing: Influencing behaviors for good. Sage: Thousand Oaks, USA, 2008.

60. McKenzie-Mohr, D., Lee, N., Schultz, W., Kotler, P. Social Marketing to Protect the Environment: What works. Sage: Thousand Oaks, USA, 2012.

61. Truong, V.D., Hall, C.M. Social marketing and tourism: What's the evidence? Soc. Mark. Q. 2013, 19, 110-135.

62. Hall, C.M. Tourism and Social Marketing. Routledge: Abingdon, UK, 2014.

63. Truong, D., Hall, C.M., Corporate social marketing in tourism: To sleep or not to sleep with the enemy? J. Sustainable Tourism 2016, DOI: 10.1080/09669582.2016.1201093.

64. Lefebvre, C. Transformative social marketing: Co-creating the social marketing discipline and brand. J. Soc. Mark. 2012, 2, 118-129.

65. Inoue, Y., Kent, A. A conceptual framework for understanding the effects of corporate social marketing on consumer behavior. J. Bus. Ethics 2014, 121, 621-633.

66. Lefebvre, R.C. Social Marketing and Social Change: Strategies and tools for improving health, well-being, and the environment. John Wiley \& Sons: Hoboken, USA, 2013.

67. Lee, N., Miller, M. Influencing positive financial behaviors: The social marketing solutions. J. Soc. Market. 2012, 2, 70-86.

68. McKenzie-Mohr, D., Smith, W. Fostering Sustainable Behavior: An Introduction to Community-Based Social Marketing; New Society Publishers: Gabriola Island, BC, Canada, 1999.

69. McKenzie-Mohr, D. Promoting sustainable behavior: An introduction to community-based social marketing. J. Soc. Issues 2000, 56, 543-544.

70. McKenzie-Mohr, D. Community-based social marketing. Water 2005, 32(2), 18-23.

71. Athey, V.L., Suckling, R.J., Tod, A.M., Walters, S.J., Rogers, T.K. Early diagnosis of lung cancer: evaluation of a community-based social marketing intervention. Thorax 2012, 67(5), 412-417.

72. Bowen, F., Newenham-Kahindi, A., Herremans, I. When suits meet roots: The antecedents and consequences of community engagement strategy. J. Bus. Ethics 2010, 95(2), 297-318. 
73. Kennedy, A.L. Using community-based social marketing techniques to enhance environmental regulation. Sustainability 2010, 2(4), 1138-1160.

74. Carrigan, M., Moraes, C., Leek, S. Fostering responsible communities: A community social marketing approach to sustainable living. J. Bus. Ethics 2011, 100(3), 515-534.

75. Hine, D.W., Crofts, R., Becker, J. Designing behaviourally informed policies for land stewardship: A new paradigm. International J. Rural Law and Policy 2015, 1. ttps://epress.lib.uts.edu.au/journals/index.php/ijrlp/article/view/4365

76. MacFadyen, L., Stead, M., Hastings, G. A Synopsis of Social Marketing. Institute for Social Marketing, University of Stirling: Stirling, https://www.stir.ac.uk/media/schools/management/documents/social_marketing.pdf.

77. Hall, C.M. Intervening in academic interventions: Framing social marketing's potential for successful sustainable tourism behavioural change, J. Sustainable Tourism 2016, 24, 350-375.

78. Hall, C.M., Dayal, N., Majstorović, D., Mills, H., Paul-Andrews, L., Wallace, C., Truong, V.D. Accommodation consumers and providers' attitudes, behaviours and practices for sustainability: A systematic review. Sustainability 2016, 8, 625.

79. Hall, C.M. Framing behavioural approaches to understanding and governing sustainable tourism consumption: Beyond neoliberalism, 'nudging' and 'green growth'? J. Sustainable Tourism 2013, 21, 1091-1109.

80. Adler, P.S.; Kwon, S.W. Social capital: Prospects for a new concept. Acad. Manag. J. 2002, 27, 17-40.

81. Putnam, R.D. Bowling Alone: The Collapse and Revival of American Community; Touchstone: New York, USA, 2000.

82. Granovetter, M.S. The strength of weak ties. American J. Sociol. 1973, 78, 1360-1380.

83. Hansen, M.T. The search-transfer problem: The role of weak ties in sharing knowledge across organization subunits. Admin. Sci. Q. 1999, 44, 82-111.

84. Barrutia, J.M., Echebarria, C. 'Networks: a social marketing tool. European J. Market. 2013, 47(1/2): $324-343$.

85. Desai, D. Role of relationship management and value co-creation in social marketing. Soc. Market. Q. 2009, 15(4): 112-125.

86. Southwell, B.G., Slater, J.S., Rothman, A.J., Friedenberg, L.M., Allison, T.R., Nelson, C.L. The availability of community ties predicts likelihood of peer referral for mammography: Geographic constraints on viral marketing. Soc. Sci. Med. 2010, 71, 1627-1635.

87. Moudatsou, M.M., Kritsotakis, G., Alegakis, A.K., Koutis, A., Philalithis, A.E. Social capital and adherence to cervical and breast cancer screening guidelines: a cross-sectional study in rural Crete. Health $\mathcal{E}$ social care in the community 2014, 22(4), 395-404.

88. Macias, T., Williams, K. Know Your neighbors, save the planet social capital and the widening wedge of pro-environmental outcomes. Environment \& Behavior 2016, 48, 391-420.

89. Mirabito, A.M., Berry, L.L. You say you want a revolution? Drawing on social movement theory to motivate transformative change. J. Service Research 2015, 18(3), 336-350.

90. Lee, C.J., Kam, J.A. Why does social capital matter in health communication campaigns?. Commun. Research 2015, 42(4), 459-481.

91. Agadjanian, V., Menjívar, C. Talking about the "Epidemic of the Millennium": religion, informal communication, and HIV/AIDS in sub-Saharan Africa. Soc. Problems 2008, 55(3), 301-321.

92. AccountAbility. AA1000 Stakeholder Engagement Standard (SES) 2015, AccountAbility: London, UK, 2015.

93. UNEP From Words to Action: The stakeholder engagement manual, Volume 2: the practitioner's handbook on stakeholder engagement. UNEP: Paris, France, 2015.

94. Freeman, L.W., Highsmith, R.P. Supplying society with natural resources: The future of mining from Agricola to Rachel Carson and beyond. The Bridge: Linking Engineering and Society 2014, 44(1), 24-32.

95. Idemudia, U. Environmental business-NGO partnerships in Nigeria: Issues and prospects. Business Strategy and the Environment 2016, DOI: 10.1002/bse.1915

96. McKenzie-Mohr, D., Schultz, P.W. Choosing effective behavior change tools. Soc. Market. Q. 2014, 20(1), $35-46$.

97. Blackstock, K.L., Kelly, G.J., Horsey, B.L. Developing and applying a framework to evaluate participatory research for sustainability. Ecological Econ. 2007, 60, 726-742.

98. Cooper, C.B., Dickinson, J., Phillips, T., Bonney, R. Citizen science as a tool for conservation in residential ecosystems. Ecology \& Society 2007, 12(2), 11. URL: http://www.ecologyandsociety.org/vol12/iss2/art11/ 
99. Quimby, C.C., Angelique, H. Identifying barriers and catalysts to fostering pro-environmental behavior: Opportunities and challenges for community psychology. American J. Commun. Psych. 2011, 47, 388-396.

100. Klenk, N., Adams, B., Bull, G., Innes, J., Cohen, S., Larson, B. Climate change adaptation and sustainable forest management: A proposed reflexive research agenda. Forestry Chron. 2011, 87(3), 351-357.

101. De Rijke, K. Coal seam gas and social impact assessment: an anthropological contribution to current debates and practices. J. Econ. Soc. Policy 2013, 15(3), 29.

102. Wilson, E., Best, S., Blackmore, E., Ospanova, S. Meaningful Community Engagement in the Extractive Industries: Stakeholder perspectives and research priorities. International Institute for Environment and Development: London, UK, 2016.

103. Hall, C.M., McArthur, S. Integrated Heritage Management, HMSO: London, UK, 1999.

104. Shackleton, S., Campbell, B., Wollenberg, E., Edmunds, D. (2002). Devolution and community-based natural resource management: Creating space for local people to participate and benefit. Natural Resour. Perspect., 76, 1-6.

105. Berkes, F. Evolution of co-management: role of knowledge generation, bridging organizations and social learning. J. Environmental Manag. 2009, 90, 1692-1702.

106. Armitage, D.R., Plummer, R., Berkes, F., Arthur, R.I., Charles, A.T., Davidson-Hunt, I.J., Diduck, A.P., Doubleday, N.C., Johnson, D.S., Marschke, M., McConney, P. Adaptive co-management for socialecological complexity. Frontiers in Ecology and the Environment 2009, 7(2), 95-102.

107. Gutiérrez, N.L., Hilborn, R., Defeo, O. Leadership, social capital and incentives promote successful fisheries. Nature 2011, 470(7334), 386-389.

108. Fasterling, B. Human rights due diligence as risk management: Social risk versus human rights risk. Business and Human Rights Journal. 2016, DOI: https://doi.org/10.1017/bhj.2016.26.

109. Kemp, D.; Owen, J.R. Community relations and mining: core to business but not "core business". Resour. Policy 2013, 38, 523-531.

(C) 2016 by the authors; licensee Preprints, Basel, Switzerland. This article is an open access article distributed under the terms and conditions of the Creative Commons by Attribution (CC-BY) license (http://creativecommons.org/licenses/by/4.0/). 